Revista Eletrônica de Direito Processual - REDP.

Rio de Janeiro. Ano 13. Volume 20. Número 2. Maio a Agosto de 2019

Periódico Quadrimestral da Pós-Graduação Stricto Sensu em Direito Processual da UERJ

Patrono: José Carlos Barbosa Moreira (in mem.). ISSN 1982-7636. pp. 20-46

www.redp.uerj.br

\title{
O SUPERIOR TRIBUNAL DE JUSTIÇA E A REPERCUSSÃO GERAL NO RECURSO ESPECIAL ${ }^{1}$
}

\section{THE SUPERIOR COURT OF JUSTICE AND THE GENERAL REPERCUSSION IN THE SPECIAL APPEAL}

Carlos Frederico Bastos Pereira

Doutorando em Direito Processual pela Universidade de São Paulo (USP). Mestre em Direito Processual pela Universidade Federal do Espírito Santo (UFES). Especializado em Direito Público pela Faculdade de Direito de Vitória (FDV). Graduado em Direito pela Universidade Federal do Espírito Santo (UFES). Professor em Cursos de Pós-Graduação de Direito Processual Civil. Membro do Instituto Brasileiro de Direito Processual (IBDP). Assessor Jurídico no Tribunal de Justiça do Espírito Santo. Vitória/ES. E-mail: fredbastospereira@gmail.com

RESUMO: O presente artigo defende a implementação de um filtro recursal para franquear o acesso ao Superior Tribunal de Justiça. Somente recursos especiais que veiculem questões infraconstitucionais dotadas de relevância e transcendência poderão ser admitidos. O Superior Tribunal de Justiça, como Corte Suprema responsável pela unidade da interpretação da lei infraconstitucional, deve julgar somente casos importantes para o desenvolvimento da ordem jurídica. É preciso harmonizar os requisitos exigidos para apreciar questões federais infraconstitucionais e constitucionais, aprendendo com os sucessos e fracassos da repercussão geral.

\footnotetext{
${ }^{1}$ Artigo recebido em 16/10/2018 e aprovado em 28/03/2019.
} 
Revista Eletrônica de Direito Processual - REDP.

Rio de Janeiro. Ano 13. Volume 20. Número 2. Maio a Agosto de 2019

Periódico Quadrimestral da Pós-Graduação Stricto Sensu em Direito Processual da UERJ

Patrono: José Carlos Barbosa Moreira (in mem.). ISSN 1982-7636. pp. 20-46

www.redp.uerj.br

PALAVRAS-CHAVE: Superior Tribunal de Justiça. Corte Suprema. Recurso Especial.

Repercussão Geral.

ABSTRACT: This paper advocates the implementation of an appeal filter to gain access to the Superior Court of Justice. Only special appeals that convey infraconstitutional issues of relevance and transcendence may be admitted. The Superior Court of Justice, as the Supreme Court responsible for the unity of the interpretation of the infraconstitutional law, must judge only important cases for the development of the legal order. It is necessary to harmonize the requirements required to assess federal infraconstitutional and constitutional issues, learning from the successes and failures of general repercussion.

KEYWORDS: Superior Court of Justice. Supreme Court. Special Appeal. General Repercussion.

SUMÁRIO: 1. Introdução; 2. Breve notícia histórica sobre os recursos excepcionais no direito brasileiro; 3. A função institucional dos tribunais superiores e a crise do STJ; 4. Os filtros recursais de seleção de casos no direito comparado; 5. Argumentos favoráveis e contrários ao filtro recursal para acesso ao STJ; 6. Semelhanças e diferenças entre arguição de relevância, repercussão geral e relevância da questão federal; 7. Questões procedimentais: aprendendo com a repercussão geral das questões constitucionais; 8. Conclusões; 9. Referências bibliográficas.

\section{INTRODUÇÃ $O^{2}$}

A realidade atual do STJ é de uma Corte inundada por recursos, com excessiva carga de trabalho e impossibilitada de cumprir a sua missão institucional de zelar pela unidade da interpretação do direito federal infraconstitucional.

\footnotetext{
${ }^{2}$ Este artigo é fruto da disciplina "Processo Civil nos Tribunais Superiores" que cursei como aluno especial no Programa de Pós-Graduação em Direito Processual da Faculdade de Direito da Universidade de São Paulo, no primeiro semestre de 2018. Agradeço aos Professores Flávio Luiz Yarshell, Heitor Vitor Mendonça Sica, João Carlos Baptista Puoli e Ricardo de Barros Leonel, responsáveis pela condução da disciplina, bem como os seus auxiliares, os Professores Daniel Penteado de Castro, Fábio Peixinho Gomes Corrêa e Igor Bimkowski Rossoni.
} 
Revista Eletrônica de Direito Processual - REDP.

Rio de Janeiro. Ano 13. Volume 20. Número 2. Maio a Agosto de 2019

Periódico Quadrimestral da Pós-Graduação Stricto Sensu em Direito Processual da UERJ

Patrono: José Carlos Barbosa Moreira (in mem.). ISSN 1982-7636. pp. 20-46

www.redp.uerj.br

Diante dessa conjuntura, é necessário pensar em instrumentos para corrigir a rota de atuação do STJ de acordo com o modelo de Corte Suprema que lhes é conferido pela ordem constitucional, dotando-o de um poder para controlar sua própria agenda, julgando única e exclusivamente casos paradigmáticos e relevantes para a sociedade brasileira, dentro de sua competência.

O presente artigo defende que os recursos especiais devem contar com filtro recursal semelhante à repercussão geral exigida nos recursos extraordinários, com o intuito de que o STJ possa colaborar no desenvolvimento da ordem jurídica. Em síntese, a ideia é que trabalhando menos, a Corte poderá trabalhar melhor.

Para tanto, analisa-se, primeiro, a gênese histórica do recurso especial; segundo, a função das Cortes de Vértice e a crise instaurada no STJ; terceiro, os filtros recursais no direito comparado; quarto, a introdução de filtro recursal qualitativo para acesso ao STJ, desenvolvendo argumentos a favor e desconstruindo argumentos contrários; quinto, as diferenças entre arguição de relevância, repercussão geral das questões constitucionais e relevância das questões infraconstitucionais, à luz da PEC n. ${ }^{\circ}$ 209/2012; sexto, propostas de ajustes para o filtro recursal das questões infraconstitucionais.

Por fim, conclui-se que a introdução de um filtro recursal qualitativo nos recursos especiais é alvissareira para o bom desempenho do STJ e para o sistema de Justiça como um todo, desde que realizados ajustes para melhoria do instituto.

\section{BREVE NOTÍCIA HISTÓRICA SOBRE OS RECURSOS EXCEPCIONAIS NO DIREITO BRASILEIRO}

Os recursos classificam-se em duas categorias muito bem definidas: os recursos ordinários e os recursos excepcionais. Apesar de certas variações na denominação - há quem preferia chamar os recursos excepcionais de recursos extraordinários, recursos de estrito direito ou recursos de sobreposição - a divisão é bem aceita em praticamente toda a doutrina ${ }^{3}$.

Os recursos ordinários buscam tutelar o direito subjetivo das partes, visando à

\footnotetext{
${ }^{3}$ Assim, cfr., BARBOSA MOREIRA, José Carlos. Comentários ao Código de Processo Civil. 15 ${ }^{\mathrm{a}}$ ed. Rio de Janeiro: Forense, 2010, vol. V (arts. 476 a 565), p. 252-257; JORGE, Flávio Cheim Teoria Geral dos Recursos Cíveis. $7^{\mathrm{a}}$ ed. São Paulo: RT, 2015, p. 52-55; MANCUSO, Rodolfo de Camargo. Recurso Extraordinário e Recurso Especial. 13a ed. São Paulo: RT, 2015, p. 129-133.
} 
Revista Eletrônica de Direito Processual - REDP.

Rio de Janeiro. Ano 13. Volume 20. Número 2. Maio a Agosto de 2019

Periódico Quadrimestral da Pós-Graduação Stricto Sensu em Direito Processual da UERJ

Patrono: José Carlos Barbosa Moreira (in mem.). ISSN 1982-7636. pp. 20-46

www.redp.uerj.br

correção da decisão recorrida; são destinados aos Tribunais ordinários, em âmbito estadual

e federal; possuem requisitos de admissibilidade menos rígidos; e comportam ampla

discussão sobre matéria de fato e de direito. Nesta categoria estão incluídos recursos como apelação e agravo de instrumento, por exemplo.

Já os recursos excepcionais tutelam o direito objetivo e buscam resguardar a integridade do ordenamento jurídico, por isso são dirigidos aos Tribunais Superiores; possuem requisitos de admissibilidades mais rígidos, além de outros requisitos definidos no texto constitucional; e não admitem rediscussão sobre matéria de fato, apenas da quaestio juris. São exemplos dessa categoria, no atual sistema brasileiro, os recursos extraordinário e especial.

No Brasil, desde a Constituição Republicana de 1891 até a Constituição de 1988, havia apenas um Tribunal Superior, o Supremo Tribunal Federal, e apenas um recurso excepcional, o extraordinário. À Suprema Corte competia julgar os recursos interpostos contra decisões que violassem questões federais, sejam elas constitucionais ou infraconstitucionais ${ }^{4}$. A Suprema Corte brasileira concentrava o julgamento das questões federais e funcionava, verdadeiramente, apenas como mais uma instância recursal na estrutura judiciária.

A reunião dessas competências acabou sobrecarregando a Corte, diagnóstico esse que ficou conhecido como "a crise do Supremo Tribunal Federal"5. O número de recursos extraordinários interpostos era superior ao número de julgamentos proferidos pela Suprema Corte, gerando, inevitavelmente, um indesejável acúmulo de trabalho.

Diversas foram as soluções propostas para combater a mencionada crise, buscando

\footnotetext{
${ }^{4}$ Interessante notar que a denominação recurso extraordinário não constava da redação original do art. 59, § $1^{\circ}$, da Constituição Republicana de 24/02/1891, sendo introduzido pioneiramente pelo art. 99 do Regimento Interno do Supremo Tribunal Federal de 08/08/1891 e doravante no art. 24 da Lei n. ${ }^{\circ} 221$ de 20/11/1894, responsável por completar a organização da Justiça Federal da Republica, conforme noticia BARBOSA MOREIRA, José Carlos. Comentários ao Código de Processo Civil, p. 582-583.

${ }^{5}$ A expressão é lugar comum nas diversas análises feitas pela doutrina brasileira quanto ao elevado número de recursos que assoberbavam o STF, cfr., por todos, BUZAID, Alfredo. A crise do Supremo Tribunal Federal. Revista da Faculdade de Direito da Universidade de São Paulo, v. 55, p. 327-372, 1960: "Sob a denominação de crise do Supremo Tribunal Federal entende-se o desequilíbrio entre o número de feitos protocolados e o de julgamento por êle proferidos; sendo a entrada daqueles consideravelmente superior à capacidade de sua decisão, vão se acumulando os processos não julgados, resultando daí o congestionamento, porque, de ano para ano, o remanescente aumenta a pirâmide de autos, chegando ao ponto de não mais poder ser removida" (op. cit., p. 346).
} 
Revista Eletrônica de Direito Processual - REDP.

Rio de Janeiro. Ano 13. Volume 20. Número 2. Maio a Agosto de 2019

Periódico Quadrimestral da Pós-Graduação Stricto Sensu em Direito Processual da UERJ

Patrono: José Carlos Barbosa Moreira (in mem.). ISSN 1982-7636. pp. 20-46

www.redp.uerj.br

sempre a redução do expressivo número de recursos que chegava à Suprema Corte ${ }^{6}$. Contudo, somente com o advento da Constituição de 1988 é que o julgamento das questões federais foi desmembrado: de um lado, ao Supremo Tribunal Federal ficou reservada tão somente a competência para julgamento da violação às questões federais constitucionais, a ser alegada por meio de recurso extraordinário (art. 102, III, CF/1988); de outro, foi criado o Superior Tribunal de Justiça especificamente para o julgamento de violação às questões federais infraconstitucionais, alegação que deveria ser feita em recurso especial (art. 105, III, $\mathrm{CF} / 1988)^{7}$.

Acreditava-se que a criação de uma nova Corte Superior seria suficiente para reduzir a excessiva carga de trabalho que assoberbava o STF, razão essa que, inclusive, levou a Constituição de 1988 a dispensar a chamada arguição de relevância, filtro recursal que buscava franquear o acesso ao STF somente dos recursos extraordinários que veiculassem questões federais relevantes ${ }^{8}$.

Porém, não foi isso que ocorreu. A única diferença, em termos pragmáticos, é que, se antes o sistema jurídico brasileiro contava apenas com uma Corte Superior sobrecarregada, passou, desde então, a contar com duas. A criação do STJ sem filtros recursais que selecionassem questões de grande relevância acabou inviabilizando uma prestação jurisdicional qualitativa9 ${ }^{9}$

Além disso, o fracionamento do antigo recurso extraordinário trouxe novos problemas ao sistema recursal, ainda sob a égide do CPC/1973. Como bem notado por Barbosa Moreira, "temos agora dois recursos em vez de um só, interponíveis ambos, em

\footnotetext{
${ }^{6}$ Já na década de 60, propondo soluções e refutando ideias para dar conta da crise no Supremo, $c f r$. LEAL, Victor Nunes. Aspectos da reforma judiciária. Revista de Informação Legislativa, v. 2, n. 7, p. 15-46, set. 1965. Para uma análise mais global das tentativas de superação da crise do Supremo - como, na divisão do autor, a arguição de relevância, óbices regimentais, o aumento do número de ministros e outras providências de caráter normativo -, cfr. MANCUSO, Rodolfo de Camargo. Recurso Extraordinário e Recurso Especial, p. 77-110.

${ }^{7}$ A proposta de criação do STJ, acolhida pela Carta Magna de 1988, é de SILVA, José Afonso da. Do Recurso Extraordinário no Direito Processual Civil Brasileiro. São Paulo: RT, 1963.

${ }^{8}$ Para uma extensa e profunda análise do instituto, NETTO, José Manoel de Arruda Alvim. Argüição de Relevância no Recurso Extraordinário. São Paulo: RT, 1988.

9 “As estatísticas revelam que, se antes tínhamos apenas um tribunal estorvado pelo volume de processos, agora temos dois sofrendo do mesmo mal. Isso porque a criação do STJ, em 1988, não foi acompanhada de instrumentos eficazes de controle do número de recursos a ele dirigidos, tornando-o, na prática, uma corte de terceira instância, à qual qualquer pessoa pode submeter seu caso" (DANTAS, Bruno; GALLOTTI, Isabel. Relevância da questão federal e a função constitucional do recurso especial. In: FUX, Luiz; DANTAS, Bruno; FREIRE, Alexandre (orgs.). Repercussão Geral da Questão Constitucional. Rio de Janeiro: Forense, 2014, p. 129-160, p. 133.
} 
Revista Eletrônica de Direito Processual - REDP.

Rio de Janeiro. Ano 13. Volume 20. Número 2. Maio a Agosto de 2019

Periódico Quadrimestral da Pós-Graduação Stricto Sensu em Direito Processual da UERJ

Patrono: José Carlos Barbosa Moreira (in mem.). ISSN 1982-7636. pp. 20-46

www.redp.uerj.br

larga medida, contra as mesmas decisões. Daí a necessidade de articulá-los; e o sistema resultante teria de ficar, como na verdade ficou, bastante complicado em mais de um ponto. É inegável que o novo regime acarreta, muitas vezes, aumento considerável na duração do processo" 10 .

O constituinte derivado buscou refrear o acesso irrestrito ao STF com a Reforma do Judiciário, implementada pela Emenda Constitucional n. ${ }^{\circ}$ 45/2004. Foram instituídas, naquela oportunidade, a eficácia vinculante das decisões proferidas em controle concentrado de constitucionalidade (art. 102, § 2º da CF/1988), a súmula vinculante (art. 103-A da CF/1988) e a repercussão geral das questões constitucionais veiculadas em recurso extraordinário (art. 102, § $3^{\circ}$, da CF/1988). Entretanto, muito embora compartilhe função institucional semelhante ao STF, não houve introdução de filtro recursal para acesso ao $\mathrm{STJ}^{11}$.

A história do recurso extraordinário e do recurso especial, com este sendo desmembrado daquele, demonstra que ambos são ontologicamente semelhantes, não havendo justificativa razoável para que um seja dotado de filtro recursal e o outro, não ${ }^{12}$. Essa constatação tanto é verdadeira que recurso extraordinário e recurso especial são tratados como espécies do mesmo gênero: os recursos excepcionais.

Essa percepção é reforçada ainda pelo perfil institucional compartilhado pelo STF e

\footnotetext{
${ }^{10}$ BARBOSA MOREIRA, José Carlos. Comentários ao Código de Processo Civil, p. 586.

${ }^{11} \mathrm{O}$ que foi lamentado à época: "O que pode causar espécie é que - numa comparação com a ilimitação de cabimento de recursos especiais - no plano do direito constitucional brasileiro haja questões constitucionais que não provoquem repercussão geral, ao passo que, no patamar relativo às questões legais de direito federal, todas elas provocam ou provocariam essa repercussão, a partir do critério de que não resultou instituído - ou, ainda não resultou instituído - esse sistema, ou análogo, para o Superior Tribunal de Justiça. Ao menos pela diversidade de tratamento dada pelo legislador constitucional, pode-se concluir desta forma" (NETTO, José Manoel de Arruda Alvim. A EC n. 45 e o instituto da repercussão geral. In: WAMBIER, Teresa Arruda Alvim et al (coords.). A Reforma do Judiciário: Primeiras Reflexões sobre a Emenda Constitucional n. ${ }^{\circ}$ 45/2004. São Paulo: RT, 2005, p. 63-99).

12 Apesar do reclamo doutrinário pela introdução de um filtro recursal de relevância em relação ao STJ, o tema ainda não foi analisado à luz do direito fundamental à igualdade (art. $5^{\circ}$, caput, da CF/1988), no sentido de não existir razão legítima suficiente para o constituinte derivado ter ofertado tratamento dessemelhante em comparação ao STF. Assim: "A igualdade na legislação pressupõe a inexistência de distinções arbitrárias no seu conteúdo. A distinção tem de ser feita de forma racional pelo legislador. É claro que a igualdade 'não consiste em um tratamento igual sem distinção de todos em todas as relações', já que 'senão aquilo que é igual deve ser tratado igualmente'. O problema da igualdade na legislação, portanto, está na utilização de critérios legítimos para distinção entre pessoas e situações no processo. É verdade, em outras palavras, a existência de 'distinções arbitrárias' na legislação, isto é, realizadas sem finalidade legítima ('legitimate purpose')" (SARLET, Ingo Wolfgang; MARINONI, Luiz Guilherme; MITIDIERO, Daniel. Curso de Direito Constitucional. $6^{\text {a }}$ ed. São Paulo: RT, 2017, p. 790).
} 
Revista Eletrônica de Direito Processual - REDP.

Rio de Janeiro. Ano 13. Volume 20. Número 2. Maio a Agosto de 2019

Periódico Quadrimestral da Pós-Graduação Stricto Sensu em Direito Processual da UERJ

Patrono: José Carlos Barbosa Moreira (in mem.). ISSN 1982-7636. pp. 20-46

www.redp.uerj.br

STJ, que será analisado a seguir.

\section{A FUNÇÃO INSTITUCIONAL DOS TRIBUNAIS SUPERIORES E A CRISE DO STJ}

Cortes que ocupam o vértice da estrutura judiciária possuem a missão institucional de zelar pela unidade na interpretação do Direito. No Brasil, ao STF compete, precipuamente, a função de guarda da Constituição, assegurando a unidade na interpretação do texto constitucional (art. 102, CF/1988); ao STJ, por sua vez, incumbe-lhe exatamente a mesma tarefa no tocante à lei infraconstitucional (art. 105, CF/1988).

Sendo assim, a manifestação dessas Cortes deve ocorrer única e exclusivamente em julgamentos com aptidão de promover o desenvolvimento da ordem jurídica, seja de maneira retrospectiva, uniformizando entendimentos controversos entre os tribunais ordinários, seja de maneira prospectiva, decidindo causas com relevância para a sociedade brasileira mesmo quando não houver um número considerável de pronunciamentos judiciais em instâncias ordinárias.

No caso específico do STJ, objeto de análise no presente trabalho, autorizá-lo a examinar toda e qualquer alegação de violação à lei federal infraconstitucional para corrigir eventuais injustiças apontadas nos acórdãos de tribunais ordinários, é admiti-lo como uma função institucional desvirtuada, semelhante a uma terceira instância, isto é, apenas mais um degrau na pirâmide judiciária. Justamente por essa razão, o STJ tem sido alçado a uma posição equivalente à do STF, ambos concebidos como verdadeiras Cortes Supremas ${ }^{13}$.

Não se defende aqui a total e absoluta equivalência das Cortes de Vértice brasileiras com, por exemplo, a Supreme Court norte-americana - modelo de Corte Suprema mais utilizado para fins de comparação jurídica ${ }^{14}$. Contudo, o hibridismo da tradição jurídica

\footnotetext{
${ }^{13}$ Sobre realocação do STJ como Corte Suprema, $c f r$, amplamente, MARINONI, Luiz Guilherme. O STJ enquanto Corte de Precedentes: Recompreensão do Sistema Processual da Corte Suprema. $2^{\mathrm{a}}$ ed. São Paulo: RT, 2014; MITIDIERO, Daniel. Cortes Superiores e Cortes Supremas: do controle à interpretação, da jurisprudência ao precedente. $3^{\mathrm{a}}$ ed. São Paulo: RT, 2017; ZANETI JR., Hermes. O Valor Vinculante dos Precedentes: Teoria dos Precedentes Normativos Formalmente Vinculantes. $3^{\text {a }}$ ed. Salvador: JusPodivm, 2017; PEREIRA, Paula Pessoa. Legitimidade dos Precedentes: Universabilidade das Decisões do STJ. São Paulo: RT, 2014.

${ }^{14}$ BARBOSA MOREIRA, José Carlos. A Suprema Corte Norte-Americana: um modelo para o mundo?. In: Temas de Direito Processual: Oitava Série. São Paulo: Saraiva, 2004, p. 239-251.
} 
Revista Eletrônica de Direito Processual - REDP.

Rio de Janeiro. Ano 13. Volume 20. Número 2. Maio a Agosto de 2019

Periódico Quadrimestral da Pós-Graduação Stricto Sensu em Direito Processual da UERJ

Patrono: José Carlos Barbosa Moreira (in mem.). ISSN 1982-7636. pp. 20-46

www.redp.uerj.br

brasileira, misturando elementos do Civil Law e do Common Law ${ }^{15}$, reforça a necessidade de pensarmos em soluções de diferentes famílias jurídicas ao sistema de administração de Justiça brasileiro para melhorar a prestação jurisdicional no âmbito das instâncias extraordinárias, sempre dotado de senso crítico para filtrar o que é e o que não é adaptável à realidade brasileira.

O próprio CPC/2015 reagiu favoravelmente à concepção do STF e do STJ como Cortes Supremas, voltadas à interpretação e unidade do direito constitucional e infraconstitucional, respectivamente.

Essa mudança pode ser percebida em três passagens do Código: (i) o art. 1.029, § $3^{\circ}$, do CPC/2015 autoriza que essas Cortes desconsiderem vício formal de recurso tempestivo ou determinem sua correção, desde que não o reputem grave; (ii) de acordo com o art. 1.025 do CPC/2015, estarão incluídos no acórdão as questões suscitadas em embargos de declaração opostos para fins de pré-questionamento, mesmo quando inadmitidos ou rejeitados; (iii) os arts. 1.032 e 1.033 do CPC/2015 estabelecem um livre trânsito entre essas Cortes no tocante à admissibilidade dos recursos extraordinários e especial. Assim, quando o relator do recurso especial entender que a questão debatida é de natureza constitucional, deverá conceder prazo para que a parte recorrente demonstre a existência de repercussão geral e se manifeste sobre a questão constitucional, remetendo-o ao STF. Igualmente, se o relator do recurso extraordinário no STF entender que a ofensa à Constituição é reflexa, também deverá remetê-lo ao STJ.

Todos esses dispositivos legais representam, em síntese, um combate à jurisprudência defensiva dos Tribunais Superiores, um verdadeiro recado do Legislador para que a atuação jurisdicional não se prenda a formalismos exacerbados na admissibilidade dos recursos excepcionais e privilegie a atuação das Cortes.

Contudo, a inserção dessas novas regras terá pouquíssimo efeito prático se for mantida a descomunal carga de trabalho nos Tribunais Superiores. Apenas para demonstrar a falência do atual modelo, dados estatísticos demonstram que, no ano de 2017, o STJ recebeu 332.284 processos; no ano de 2016, foram 335.825; e, no ano de 2015, foram

\footnotetext{
${ }^{15}$ Sobre o ponto, ZANETI JR., Hermes. A Constitucionalização do Processo: o Modelo Constitucional da Justiça Brasileira e as Relações entre Processo e Constituição. $2^{\mathrm{a}}$ ed. São Paulo: Atlas, 2014.
} 
Revista Eletrônica de Direito Processual - REDP.

Rio de Janeiro. Ano 13. Volume 20. Número 2. Maio a Agosto de 2019

Periódico Quadrimestral da Pós-Graduação Stricto Sensu em Direito Processual da UERJ

Patrono: José Carlos Barbosa Moreira (in mem.). ISSN 1982-7636. pp. 20-46

www.redp.uerj.br

$327.841^{16}$. Façamos o seguinte exercício, apenas a título de imaginação: considerando que o

STJ é composto por 33 ministros, cada um recebeu, em 2017, 10.069 processos; para julgar

todos eles, cada ministro deveria finalizar 27 processos por dia - isso se for considerado

como dias trabalhados todos os 365 dias do ano. Trata-se de tarefa absolutamente impraticável.

Como o julgamento nestes moldes é humana e materialmente impossível, as (significativas e importantes) mudanças introduzidas pelo $\mathrm{CPC} / 2015$ para combater a jurisprudência defensiva terão uma repercussão muito reduzida, visto que outras interpretações formalistas serão realizadas para impedir que a avalanche de recursos especiais alcance o $\mathrm{STJ}^{17}$, o que, por sinal, já vem ocorrendo ${ }^{18}$. A interpretação restritiva dos requisitos de admissibilidade dos recursos especiais acaba funcionando como uma solução utilitarista para a redução da carga de trabalho.

Dotar essas Cortes do poder de autogoverno, inclusive o STJ, selecionando recursos a partir de um filtro recursal transparente e controlável, até mesmo para superar óbices formais quando estiver diante de uma questão relevante para a sociedade, é a saída adequada para essa questão ${ }^{19}$. É necessário julgar menos para julgar melhor.

\section{OS FILTROS RECURSAIS DE SELEÇÃO DE CASOS NO DIREITO COMPARADO}

\footnotetext{
16 Dados retirados dos Boletins Estatísticos do Superior Tribunal de Justiça, disponíveis no site: <http://www.stj.jus.br/webstj/Processo/Boletim/?vPortalAreaPai=183\&vPortalArea=584>. Acesso em 19.06.2018.

${ }^{17} \mathrm{O}$ que já foi alertado por uma parte doutrina: "E de pouco ou nada adiantará, com efeito, a reação do novo Código de Processo Civil aos excessos da jurisprudência defensiva (...), a solução do problema não depende da boa vontade dos ministros do Superior Tribunal de Justiça, que apenas encontrará novos meios para adaptar a jurisprudência defensiva às exigências do novo CPC se nada eficaz vier a ser concretamente feito" BENEDUZI, Renato Resende. Repercussão geral no recurso especial por analogia. Disponível em <https://puc-rio.academia.edu/RenatoBeneduzi>. Acesso em 19.06.2018.

${ }^{18}$ A Corte Especial do STJ decidiu que a falta de comprovação de feriado local ou de suspensão de prazo processual no tribunal de origem no momento em que interposto o recurso especial constitui vício insanável e, portanto, não incide a possibilidade de correção do vício, autorizada pelo art. 1.029, § 3º do CPC/2015. (AgInt no AREsp 957.821/MS, Rel. Ministro Raul Araújo, Rel. p/ Acórdão Ministra Nancy Andrighi, Corte Especial, julgado em 20/11/2017, DJe 19/12/2017).

${ }^{19}$ São raras as manifestações do STJ quanto à relevância da questão federal debatida: "Ostentando a questão federal ventilada no recurso especial relevância jurídica, econômica e social a desafiar o conhecimento do apelo, propicia-se ao STJ que se proceda à interpretação final da lei federal e, por conseguinte, se desincumba de sua missão constitucional de assegurar a inteireza do direito federal infraconstitucional” (AgRg no Ag 1.322.327/RJ, Rel. Ministro João Otávio de Noronha, Quarta Turma, julgado em 05/10/2010, DJe 07/02/2011; AgRg na RCDESP no REsp 1347719/PR, Rel. Ministro Luis Felipe Salomão, Quarta Turma, julgado em 26/02/2013, DJe 04/03/2013).
} 
Revista Eletrônica de Direito Processual - REDP.

Rio de Janeiro. Ano 13. Volume 20. Número 2. Maio a Agosto de 2019

Periódico Quadrimestral da Pós-Graduação Stricto Sensu em Direito Processual da UERJ

Patrono: José Carlos Barbosa Moreira (in mem.). ISSN 1982-7636. pp. 20-46

www.redp.uerj.br

A inserção de filtros recursais que limitam o acesso aos Tribunais Superiores com base em critérios qualitativos para seleção de casos é uma tendência mundial, adotada em países de diferentes tradições jurídicas e com diferentes estruturas judiciárias ${ }^{20}$.

Nos Estados Unidos, a Supreme Court possui ampla discricionariedade para decidir quais recursos julgará, o que vem regulamentado desde o Judiciary Act de 1925. Nas Rules of the Supreme Court of the United States, espécie de regimento interno da Suprema Corte norte-americana, mais especificamente a Rule 10, enuncia-se que o exame do writ of certiorari (equivalente à repercussão geral da matéria) não é uma questão de direito, mas de discricionariedade judicial ("review on a writ of certiorari is not a matter of right, but of judicial discretion").

Nos Estados Unidos, o sistema de seleção qualitativo dos recursos que serão analisados pela Supreme Court contém fortes elementos de discricionariedade, autorizando a Corte a rejeitá-la ou aceitá-la sem a obrigatoriedade de fundamentação.

No Brasil, esse modus operandi esbararia, a princípio, no art. 93, IX, da CF/1988. Bem vistas as coisas, esse sistema discricionário já foi rejeitado, com a revogação da arguição de relevância, que não era fundamentada, e a posterior adoção da repercussão geral das questões constitucionais, esta sim, que deve ser fundamentada ${ }^{21}$.

$\mathrm{Na}$ Alemanha, também há previsão de um requisito qualitativo para admissibilidade da Revision e acesso ao Bundesverfassungsgericht (BVerfG), equivalentes, respectivamente, ao recurso especial e ao STJ, no Brasil. No país tedesco, é necessária que a Revision veicule uma significação fundamental (grundsätzliche Bedeutung, § 543, da ZPO).

Como noticia Antonio do Passo Cabral, “entende-se que haverá significação fundamental quando o debate na instância superior possa aclarar ou responder a uma quaestio juris que transcenda os limites do processo sob exame e possa servir para uma séria

\footnotetext{
${ }^{20}$ Para uma ampla análise do direito comparado nesta matéria, notadamente os sistemas jurídicos dos Estados Unidos, Alemanha, Argentina, Inglaterra, Canadá, Austrália e Japão, cfr. DANTAS, Bruno. Repercussão Geral: Perspectivas Histórica, Dogmática e de Direito Comparado - Questões Processuais. $2^{\mathrm{a}}$ ed. São Paulo: RT, 2009, p. 90-131.

${ }^{21}$ Para uma análise comparativa, MACIEL, Adhemar Ferreira. Restrição à admissibilidade de recursos na Suprema Corte dos Estados Unidos e no Supremo Tribunal Federal do Brasil. Revista de Informação Legislativa, a. 43, n. 170, p. 7-15, abr./jun. 2006.
} 
Revista Eletrônica de Direito Processual - REDP.

Rio de Janeiro. Ano 13. Volume 20. Número 2. Maio a Agosto de 2019

Periódico Quadrimestral da Pós-Graduação Stricto Sensu em Direito Processual da UERJ

Patrono: José Carlos Barbosa Moreira (in mem.). ISSN 1982-7636. pp. 20-46

www.redp.uerj.br

de casos não previamente determinada de casos futuros"22. Haverá significação fundamental,

ainda, quando estiver em discussão "certos âmbitos normativos que tenham sido regrados

muito recentemente", "princípios processuais fundamentais tenham sido (alegadamente)

violados" ou quando o debate "colabore para o desenvolvimento do Direito ou para uniformização da jurisprudência"23.

A Alemanha, claramente, tem uma preocupação qualitativa com a matéria sobre qual a Corte irá sobre pronunciar, restringindo a sua atuação. Trata-se de modelo apto a servir de inspiração a eventual filtro recursal de relevância das questões federais infraconstitucionais no Brasil.

Na Itália, uma lei promulgada em meados de 2009 introduziu um filtro ao recurso de cassação por meio do art. 360-bis do CPC, prescrevendo que o mesmo deve ser inadmitido em duas hipóteses: (i) quando o provimento jurisdicional objeto de impugnação estiver de acordo com a jurisprudência da Corte di Cassazione ou não oferecer elementos idôneos o suficiente para alterar a orientação da Corte; (ii) quando for manifestamente infundada a censura relativa à violação dos princípios reguladores do giusto processo.

Ainda que mais modesto - principalmente se comparado ao certiorari americano e à significação fundamental alemã ${ }^{24}-$, o filtro recursal italiano confirma a tendência mundial para as Cortes de Vértice, ainda que a sua inserção na ordem italiana seja controversa na doutrina local ${ }^{25}$.

\footnotetext{
${ }^{22}$ CABRAL, Antonio do Passo. Requisitos de relevância no sistema recursal alemão. In: FUX, Luiz; DANTAS, Bruno; FREIRE, Alexandre (orgs.). Repercussão Geral da Questão Constitucional. Rio de Janeiro: Forense, 2014, p. 71-85, esp. 79. Sobre o tema, ver, ainda, PÉREZ RAGONE, Alvaro J. El nuevo proceso civil alemán: principios y modificaciones al sistema recursivo. Genesis - Revista de Direito Processual Civil, v. 9, n. 32, p. 357-384, abr./jun. 2004.

${ }^{23}$ CABRAL, Antonio do Passo. Requisitos de relevância no sistema recursal alemão, p. 79.

${ }^{24}$ Em estudo comparativo entre a Corte di Cassazione italiana e o Bundesgerichtshof tedesco, Remo Caponi afirma que a Corte alemã tem uma atuação sostanzialmente efficiente, dentre outras questões, "grazie anche al filtro selettivo dei ricorsi introdotto nel 1975", enquanto a Corte itailiano sucumbe na sua tarega "afflitta dalla marea crescente dei ricorsi e dalle proprie interne disfunzioni organizzative" (CAPONI, Remo. La decisione della causa nel merito da parte della Corte di cassazione italiana e del Bundesgerichtshof tedesco. Diritto $e$ Giurisprudenza, 1996, p. 236 e ss.).

${ }^{25}$ Giovanni Bonato descreve a discussão “(...) os estudioso italianos se dividiram entre: quem sustenta a necessidade de restringir o acesso à Corte de Cassação, para erigi-la em verdadeira Corte de Precedentes; aqueles que, contrariando essa visão, consideram o recuso de cassação como um elemento essencial e imprescindível do 'devido processo legal' que deve, portanto, sempre ser assegurado à parte sucumbente; por fim, os demais doutrinadores que são favoráveis a uma restrição ao recurso de cassação desde que haja uma modificação do art. 111 , parte $7^{\circ}$, da Constituição, que assegura sem limitação o cabimento do remédio sob enfoque, não podendo o legislador infraconstitucional violar essa garantia constitucional" (BONATO, Giovanni. O filtro ao recurso de cassação no sistema jurídico italiano. Revista de Processo, v. 40, n. 249, p.
} 
Revista Eletrônica de Direito Processual - REDP.

Rio de Janeiro. Ano 13. Volume 20. Número 2. Maio a Agosto de 2019

Periódico Quadrimestral da Pós-Graduação Stricto Sensu em Direito Processual da UERJ

Patrono: José Carlos Barbosa Moreira (in mem.). ISSN 1982-7636. pp. 20-46

www.redp.uerj.br

$\mathrm{Na}$ Espanha, o item n. ${ }^{\circ} 1$ do artículo 477 da Ley de Enjuiciamiento Civil afirma que

"El recurso de casación habrá de fundarse, como motivo único, en la infracción de normas aplicables para resolver las cuestiones objeto del proceso". Logo em seguida, o item n. ${ }^{\circ} 2$ do mencionado dispositivo elenca três hipóteses que autorizam o acesso à instância extraordinária: (i) quando visaram à tutela judicial civil de derechos fundamentales; (ii) quando o proveito econômico da causa for maior que 600.000 euros; e (iii) nos casos em que o proveito econômico da causa for menor que 600.000 euros, houver interés casacional.

E densificando o que se entende por interés casacional, continua o dispositivo dizendo que o mesmo estará presente quando (i) a decisão impugnada for contrária à doctrina jurisprudencial do Tribunal Supremo; (ii) quando houver divergência nos tribunais de segundo grau; e (iii) quando decisão impugnada tiver aplicado normas em vigor há menos de cinco anos, ressalvada a hipótese de jurisprudência consolidada do Tribunal Supremo quanto a normas anteriores de igual ou similar conteúdo.

O ordenamento jurídico espanhol também adota um filtro recursal de relevância para o enfrentamento de questões pela Corte Suprema do país. Mais que isso, a lei processual espanhola explicita várias hipóteses nas quais o reconhecimento da relevância é mandatório, o que não é percebido no Brasil, que relega à atuação jurisdicional a concretização dos conceitos de relevância e transcendência no âmbito da repercussão geral das questões constitucionais.

Na Argentina, a Suprema Corte é competente para julgar o recurso extraordinário que versa sobre alegação de violação a questões federais constitucionais e infraconstitucionais, assim como ocorria no Brasil até a Constituição de $1988^{26}$. A inspiração, tal qual a brasileira, era no direito norte-americano. Foi somente em meados de 1990 que uma lei argentina introduziu um filtro recursal, alterando o Código Procesal Civil y Comercial de la Nación. A alteração legislativa do art. 280 do referido código passou a prever que a Suprema Corte, "según su sana discreción", não conhecerá do recurso extraordinário por "falta de agravio federal suficiente" ou quando as questões "resultaren insustanciales" ou "carentes de trascendencia".

\footnotetext{
249-274, nov. 2015).

${ }^{26}$ Comparando os sistemas brasileiro e argentino, $c f r$. DANTAS, Bruno. Repercussão geral: algumas lições da Corte Suprema argentina ao Supremo Tribunal Federal brasileiro. Revista de Informação Legislativa, v. 47, n. 187, p. 35-43, jul./set. 2010.
} 
Revista Eletrônica de Direito Processual - REDP.

Rio de Janeiro. Ano 13. Volume 20. Número 2. Maio a Agosto de 2019

Periódico Quadrimestral da Pós-Graduação Stricto Sensu em Direito Processual da UERJ

Patrono: José Carlos Barbosa Moreira (in mem.). ISSN 1982-7636. pp. 20-46

www.redp.uerj.br

A doutrina argentina entende que os critérios da insuficiencia e da insubstancialidad são filtros impróprios, ou seja, mecanismos de agilização do processo decisório; já o critério da transcendencia constitui um filtro próprio, isto é, um filtro de seleção de casos propriamente dito, chegando a denominá-lo de "certiorari argentino"27. A discricionariedade, porém, não seria absoluta. A lei, inclusive, qualifica a discricionariedade como $\operatorname{sana}^{28}$, algo como uma discricionariedade razoável e prudente.

Diante de todas essas observações extraídas do direito comparado, nota-se que um Tribunal Superior não deve funcionar como instância recursal, mas, por ocupar o vértice da estrutura judiciária, deve conter filtros recursais que privilegiem a atuação da Corte em casos de notável importância.

\section{ARGUMENTOS FAVORÁVEIS E CONTRÁRIOS AO FILTRO RECURSAL PARA ACESSO AO STJ}

Uma das características das Cortes Supremas, perfeitamente adaptável às Cortes de Vértice brasileiras, consiste na possibilidade de controlarem sua própria agenda para julgar apenas casos paradigmáticos e com relevância para a sociedade. Na lição da doutrina, em um modelo de Corte Suprema "o recurso passa a ser viabilizado no interesse do jus constitutionis, isto é, no interesse da unidade do Direito, e não para tutela do jus litigatoris, sendo então apropriado cogitar da imposição de condições especiais para admissão do recurso à Corte Suprema" 29 .

No Brasil, o STF conta com a repercussão geral, filtro recursal de admissibilidade baseado na relevância e transcendência das questões constitucionais. O STJ, por sua vez, não conta com filtro recursal para admissibilidade das questões federais infraconstitucionais, em que pese ser a Corte responsável por dar unidade à lei federal infraconstitucional.

Dois argumentos são comumente utilizados pela não instituição de um filtro recursal para o STJ. Primeiro, que haveria uma restrição do acesso à justiça ao impedir a atuação

\footnotetext{
${ }^{27}$ GIANINNI, Leandro J. El certiorari en Argentina: la trascendencia como filtro de selección ante la Corte Suprema. Revista de Processo, v. 41, n. 251, p. 229-273, jan. 2016.

${ }^{28}$ OTEIZA, Eduardo. El certiorari o el uso de la discrecionalidad por la Corte Suprema de Justicia de la Nación sin rumbo preciso. Revista Jurídica de la Universidad de Palermo, año 3, n. 1, p. 71-85, 1998.

${ }^{29}$ MITIDIERO, Daniel. Cortes Superiores e Cortes Supremas, p. 82.
} 
Revista Eletrônica de Direito Processual - REDP.

Rio de Janeiro. Ano 13. Volume 20. Número 2. Maio a Agosto de 2019

Periódico Quadrimestral da Pós-Graduação Stricto Sensu em Direito Processual da UERJ

Patrono: José Carlos Barbosa Moreira (in mem.). ISSN 1982-7636. pp. 20-46

www.redp.uerj.br

daquela Corte ${ }^{30}$; segundo, que haveria uma perpetuação de erros judiciais cometidos pelas instâncias ordinários.

Ambos não convencem.

O primeiro carece de um acordo semântico sobre o que efetivamente significa acesso à justiça. Sem uma base conceitual sobre a amplitude e extensão do acesso à justiça, não é possível afirmar se essa garantia está ou não sendo objeto de restrição.

E o acesso à justiça não se limita ao poder do jurisdicionado em provocar o Poder Judiciário. Mais que isso, o acesso à justiça projeta sua eficácia antes e durante o desenvolvimento do processo ${ }^{31}$. Antes, porque o Legislador deve disponibilizar ao jurisdicionado instrumentos hábeis e adequados à tutela do seu direito. São exemplos dessa concepção, a assistência judiciária gratuita e o sistema de justiça multiportas, com a mediação, a conciliação e a arbitragem. Também durante o desenvolver do processo, o legislador deve prover ao jurisdicionado técnicas processuais para que a tutela do seu direto seja prestada de modo adequado, efetivo e tempestivo ( $v \cdot g$. tutelas provisórias de urgência e de evidência, dinamização e inversão do ônus da prova, combinação de meios típicos e atípicos de execução, duplo grau de jurisdição etc.).

Assim, a introdução do filtro recursal de admissibilidade do recurso especial não restringe o acesso à justiça, efetivando-se plenamente com o duplo grau de jurisdição nas

\footnotetext{
${ }^{30}$ Neste sentido, "O STF é Corte Constitucional e, portanto, há plena justificativa para a implementação do requisito de limitação de admissibilidade que é a repercussão geral do recurso extraordinário. No caso do STJ, pensamos que o panorama é relativamente diverso. Embora não passe despercebida a magnitude dessa Corte, verdadeira instância extraordinária, seu específico papel constitucional ainda parece ser pouco estudado. A limitação de admissibilidade do recurso especial, quando ausente a relevância da questão federal discutida, talvez implique em limitação inadequada da atuação daquela Corte" (SERAU JR., Marco Aurélio; DONOSO, Denis. Relevância da questão federal como filtro de admissibilidade do recurso especial: análise das propostas de emenda constitucional. Revista de Processo, v. 38, n. 224, p. 241-251, out. 2013).

${ }^{31}$ Nesse sentido, como referido por Ada Pellegrini Grinover, "(i) a organização judiciária adequada à realidade do país, com sua modernização e realização de pesquisa permanente para o conhecimento dessa realidade e dos conflitos que nela ocorrem; (ii) a organização de serviços voltados ao tratamento adequado das controvérsias, inclusive com utilização de mecanismos diversos do processo estatal, como a arbitragem e os meios consensuais de solução de conflitos, dentre os quais se destacam a mediação e a conciliação; (iii) a adequação dos instrumentos processuais à efetiva tutela dos direitos individuais e coletivos dos jurisdicionados; (iv) a prestação adequada dos serviços de assistência jurídica integra, que propicie não somente o acesso aos órgãos da jurisdição (estatal ou não), como também orientação e informação jurídica; (v) a formação adequada dos juízes, dos árbitros e de terceiros facilitadores e seu permanente aperfeiçoamento; (vi) a remoção dos diferentes obstáculos (econômico, social, cultural, e de outras espécies) que se anteponham ao acesso à ordem jurídica justa; e (vii) pesquisa interdisciplinar permanente para o aperfeiçoamento do direito material" (GRINOVER, Ada Pellegrini. Ensaio Sobre a Processualidade: Fundamentos para uma Nova Teoria Geral do Processo. Brasília: Gazeta Jurídica, 2017, p. 75-76).
} 
Revista Eletrônica de Direito Processual - REDP.

Rio de Janeiro. Ano 13. Volume 20. Número 2. Maio a Agosto de 2019

Periódico Quadrimestral da Pós-Graduação Stricto Sensu em Direito Processual da UERJ

Patrono: José Carlos Barbosa Moreira (in mem.). ISSN 1982-7636. pp. 20-46

www.redp.uerj.br

instâncias ordinárias. Não é possível ignorar o fato de que há toda uma estrutura judiciária que se desenvolve no primeiro e segundo grau de jurisdição, em âmbito estadual e federal, promovendo o acesso à justiça ${ }^{32}$.

Ademais, o duplo grau de jurisdição deve ser concebido como "aquele sistema jurídico em que, para cada demanda, existe a possibilidade de duas decisões válidas e completas no mesmo processo, emanados por juízos diferentes, prevalecendo sempre a segunda em relação à primeira" ${ }^{33}$. Não há um terceiro grau de jurisdição no sistema jurídico brasileiro, pois o mesmo teria de ser "válido e completo", permitindo, inclusive, a total revisão da decisão impugnada ${ }^{34}$.

Quanto ao fato de que erros judiciais não seriam corrigidos pelos recursos especiais, é preciso deixar claro que o próprio STJ não é uma Corte imune a erros. Como Ovídio Baptista denuncia, "a revisão de nosso sistema recursal (...) exige que se tenha presente que as Cortes Supremas não são infalíveis e cometem igualmente injustiças, como os homens e suas organizações politicas e sociais haverão de cometê-las sempre" ${ }^{\text {"35 }}$. O erro está em acreditar em um tribunal capaz de não cometer erros.

Ademais, caso se entenda que necessidade de correção das decisões judiciais é um imperativo inadiável para o bom funcionamento do sistema de justiça, haveria de ser concebida uma instância de correção das instâncias extraordinárias, uma instância de correção da instância de correção das instâncias extraordinárias e assim sucessivamente.

É preciso admitir que o sistema jurídico habita o plano humano - falível, portanto e que não há uma instância recursal imune a equívocos. Não se pode esquecer também que um dos escopos do processo civil é a pacificação social, sendo a eternização dos conflitos

\footnotetext{
32 “(...) constitui-se equívoco injustificável ligar-se à circunstância do Superior Tribunal de Justiça apreciar só questões relevantes a um problema de acesso à Justiça, porque, para realizar o acesso à Justiça, há uma estrutura, no país, que desdobra nas diversas justiças estaduais, de um lado, e, de outro, na justiça federal, cujos organismos cobre todo o nosso território. Esses aparelhos judiciários desdobram-se dois graus de jurisdição" (NETTO, José Manoel de Arruda Alvim. A alta função jurisdicional do Superior Tribunal de Justiça no âmbito do recurso especial e a relevância das questões. Revista de Processo, v. 24, n. 96, p. 37-44, out./dez. 1999). Em igual sentido, $c f r$. RODOVALHO, Thiago. O STJ e a arguição de relevância. In: GALOTTI, Isabel et al (coords.). O Papel da Jurisprudência no STJ. São Paulo: RT, p. 835-854, 2014, p. 847.

${ }^{33}$ LASPRO, Orestes Nestor de Souza. O Duplo Grau de Jurisdição no Processo Civil. São Paulo: RT, 1995, p. 27.

${ }^{34}$ AZZONI, Clara Moreira. Recurso Especial e Extraordinário: Aspectos Gerais e Efeitos. São Paulo: Atlas, 2009 , p. 43.

${ }^{35}$ SILVA, Ovídio Araújo Baptista da. A Função dos Tribunais Superiores. In: Sentença e Coisa Julgada: Ensaios e Pareceres. $4^{\mathrm{a}}$ ed. Rio de Janeiro: Forense, 2006, p. 285-305, p. 295.
} 
Revista Eletrônica de Direito Processual - REDP.

Rio de Janeiro. Ano 13. Volume 20. Número 2. Maio a Agosto de 2019

Periódico Quadrimestral da Pós-Graduação Stricto Sensu em Direito Processual da UERJ

Patrono: José Carlos Barbosa Moreira (in mem.). ISSN 1982-7636. pp. 20-46

www.redp.uerj.br

um elemento nocivo para a sociedade em geral $^{36}$.

De outro lado, consequências benéficas poderão surgir com a inserção de um filtro de relevância nos recursos especiais para acesso ao STJ.

Isso porque a legislação federal infraconstitucional no Brasil é bastante extensa, muito por causa da ampla competência legislativa atribuída em caráter privativo à União (art. 22, da CF/1988). O Poder Judiciário, em sua maioria, aplica a lei federal infraconstitucional, o que gera uma sobreposição de interpretações e autoriza os jurisdicionados a buscarem, perante o STJ, a reversão de muitas das decisões proferidas em instâncias ordinárias, transformando-o em terceira instância recursal.

Se adotado o filtro de relevância das questões federais infraconstitucionais, haverá, de um lado, o fortalecimento dos Tribunais ordinários, que não mais funcionarão como mera instância de passagem. De outro, o aumento de questões decididas pelas instâncias ordinárias levará ao amadurecimento do debate, de modo que, havendo divergência no âmbito de um mesmo tribunal ou entre diferentes tribunais, o reconhecimento da relevância será ainda mais imperioso para unidade da interpretação, com a formação de precedentes mais qualificados.

Como se pode notar, são mais que suficientes as razões para introduzir um filtro recursal de relevância no STJ.

\section{SEMELHANÇAS E DIFERENÇAS ENTRE ARGUIÇÃO DE RELEVÂNCIA, REPERCUSSÃO GERAL E RELEVÂNCIA DA QUESTÃo FEDERAL}

Eventual introdução de um filtro recursal de admissibilidade para as questões federais infraconstitucionais passará, inevitavelmente, pelos seus antecedentes históricos: a arguição de relevância nos recursos extraordinários, existente até a Constituição de 1988, e a repercussão geral das questões constitucionais, nela introduzida pela Emenda Constitucional n. ${ }^{\circ} 45 / 2004$.

\footnotetext{
36 "De igual sorte, também não prospera a crítica feita em razão do erro judicial. Se, de fato, um menor acesso às instâncias extraordinárias pode fazer com que um erro judicial cometido pelas instâncias ordinárias transite em julgado, de outro turno, a busca por um justo absoluto não tem produzido bons resultados, senão, como dito acima, a loterização da justiça e a eternização do processo, com erros judiciais ainda transitando em julgado (aliás, nem as Cortes Extraordinárias, na qualidade de também cortes humanas, estão infensas a cometer erros judiciais)" (RODOVALHO, Thiago. O STJ e a arguição de relevância, p. 848).
} 
Revista Eletrônica de Direito Processual - REDP.

Rio de Janeiro. Ano 13. Volume 20. Número 2. Maio a Agosto de 2019

Periódico Quadrimestral da Pós-Graduação Stricto Sensu em Direito Processual da UERJ

Patrono: José Carlos Barbosa Moreira (in mem.). ISSN 1982-7636. pp. 20-46

www.redp.uerj.br

Tramita perante o Congresso Nacional a PEC n. ${ }^{\circ}$ 209/2012, para inserir um filtro recursal de relevância para as questões federais infraconstitucionais, com a seguinte redação: "Nos termos da lei, o recorrente deverá demonstrar no recurso especial a relevância das questões de direito federal infraconstitucional discutidas no caso, a fim de que o Tribunal examine a admissão do recurso, somente podendo recusá-lo pela manifestação de dois terços dos membros do órgão competente para o julgamento" 37 .

Como se pode notar, a redação fala apenas em relevância das questões de direito federal infraconstitucional, motivo pelo qual é oportuno, primeiramente, estabelecer um estudo comparativo entre a arguição de relevância e a repercussão geral ${ }^{38}$, e, num segundo momento, analisar eventual semelhança da relevância das questões federais infraconstitucionais com cada instituto.

Primeiro, a arguição de relevância. O art. 119, III, da Constituição de 1967, alterado pela Emenda Constitucional n. ${ }^{\circ} 1 / 1969$, previa a competência do STF quando do julgamento de recurso extraordinário, estabelecendo, no parágrafo único do referido dispositivo, que as causas ali delineadas "serão indicadas pelo Supremo Tribunal Federal no regimento interno, que atenderá à sua natureza, espécie ou valor pecuniário”.

No Regimento Interno do STF, alterado pela Emenda Regimental n. ${ }^{o} 2$ de 04.12.85, previu-se, no art. 327, que "ao Supremo Tribunal Federal, em sessão de Conselho, compete privativamente o exame da argüição de relevância da questão federal”, dizendo, no $\S 1^{\circ}$, que “entende-se relevante a questão federal que, pelos reflexos na ordem jurídica, e considerados os aspectos morais, econômicos, políticos ou sociais da causa, exigir a apreciação do recurso extraordinário pelo Tribunal".

A repercussão geral, por sua vez, foi introduzida na Constituição de 1988 pela Emenda Constitucional n. ${ }^{\circ} 45$ de 2004, que inseriu o $\S 3^{\circ}$ no art. 102 da Carta Magna, cuja

\footnotetext{
${ }^{37} \mathrm{O}$ Conselho Federal da Ordem dos Advogados do Brasil se manifestou contrariamente à aprovação da Emenda Constitucional "em virtude da restrição que isso importaria no acesso ao STJ, renegando, mesmo, a razão histórica determinante da criação desse Tribunal Superior pela Constituição de 1988. Amplitude que devem ter, em tese, os recursos de natureza extraordinária para o Supremo Tribunal Federal e o Superior Tribunal de Justiça, dado o seu fim precípuo, que é o de manter a unidade do direito federal" (MEDINA, Paulo Roberto de Gôuvea. Arguição de relevância no STJ. Revista Brasileira de Direito Processual, v. 25, n. 98, p. 357-363, abr./jun. 2017).

${ }^{38}$ Sobre as diferenças entre repercussão geral e arguição de relevância, ver LAMY, Eduardo de Avelar. Repercussão geral no recurso extraordinário: a volta da arguição de relevância?. In: WAMBIER, Teresa Arruda Alvim et al (orgs.). Reforma do Judiciário. São Paulo: RT, 2005, p. 167-180.
} 
Revista Eletrônica de Direito Processual - REDP.

Rio de Janeiro. Ano 13. Volume 20. Número 2. Maio a Agosto de 2019

Periódico Quadrimestral da Pós-Graduação Stricto Sensu em Direito Processual da UERJ

Patrono: José Carlos Barbosa Moreira (in mem.). ISSN 1982-7636. pp. 20-46

www.redp.uerj.br

redação dizia que "no recurso extraordinário o recorrente deverá demonstrar a repercussão geral das questões constitucionais discutidas no caso, nos termos da lei, a fim de que o Tribunal examine a admissão do recurso, somente podendo recusá-lo pela manifestação de dois terços de seus membros".

$\mathrm{O}$ instituto veio posteriormente regulado no art. 543-A e 543-B do CPC/1973, inseridos pela Lei n. ${ }^{\circ} 11.418$, de 2006 , e atualmente no art. 1.035 do CPC/2015, cujo $\S 1^{\circ}$ afirma que "para efeito de repercussão geral, será considerada a existência ou não de questões relevantes do ponto de vista econômico, político, social ou jurídico que ultrapassem os interesses subjetivos do processo".

Primeiro ponto a ser destacado é que não havia STJ e recurso especial à época da arguição de relevância e o julgamento de violação à Constituição e à lei federal infraconstitucional era concentrado no STF. O exame da repercussão geral, por sua vez, compete ao STF quando veiculado em recurso extraordinário que julga violação a questão estritamente constitucional.

Segundo ponto que merece observação é que a arguição de relevância tinha como pressuposto básico a inclusão de matérias no âmbito de análise do recurso extraordinário, as quais não seriam apreciáveis, em linha de princípio, por contar com limitações regimentais ${ }^{39}$. Já a repercussão geral pretende excluir do conhecimento do STF matérias que não a contenham $^{40}$.

Terceiro ponto a ser levado em consideração é que o exame da arguição de relevância ocorria em sessão secreta e era desprovido de fundamentação, razão pela uma parcela da doutrina apontava a inconstitucionalidade dessa "esdrúxula e misteriosa medida (...) com falta de índole democrática" ${ }^{41}$. O preenchimento ou não dos requisitos de configuração da repercussão geral, muito diferentemente, deve ser analisado em sessão pública e

\footnotetext{
${ }^{39}$ Arruda Alvim fala que "a arguição de relevância fornece o caminho adequado para incluir o que tenha sido objeto de exclusão por obra do Regimento Interno, que vale como lei, neste particular” (NETTO, José Manoel de Arruda Alvim. Argüição de Relevância no Recurso Extraordinário, p. 27).

${ }^{40}$ Assim, MARINONI, Luiz Guilherme; MITIDIERO, Daniel. Repercussão Geral no Recurso Extraordinário. $3^{\mathrm{a}}$ ed. São Paulo: RT, 2012, p. 37; LAMY, Eduardo de Avelar. Repercussão geral no recurso extraordinário: a volta da arguição de relevância?, p. 178.

${ }^{41}$ Expressões de LIMA, Alcides de Mendonça. Arguição de relevância da questão federal. Revista de Processo, v. 15, n. 58, p. 118-119, abr./jun. 1990. Para um exame completo da inconstitucionalidade, $c f r$. CALMON DE PASSOS, José Joaquim. Da arguição de relevância no recurso extraordinário. Revista Forense: Comemorativa - 100 anos, 2007, v. 1, p. 581-607.
} 
Revista Eletrônica de Direito Processual - REDP.

Rio de Janeiro. Ano 13. Volume 20. Número 2. Maio a Agosto de 2019

Periódico Quadrimestral da Pós-Graduação Stricto Sensu em Direito Processual da UERJ

Patrono: José Carlos Barbosa Moreira (in mem.). ISSN 1982-7636. pp. 20-46

www.redp.uerj.br

fundamentação é obrigatória, por imperativo constitucional expresso (art. 93, IX, da $\mathrm{CF} / 1988)$.

Quarto e último ponto a ser notado é que o conceito de arguição de relevância fixase única e exclusivamente na ideia de relevância, enquanto a repercussão geral conjuga dois elementos: relevância e transcendência ${ }^{42}$. Muito longe de constituir um mero jogo de palavras, relevância e transcendência são conceitos jurídicos indeterminados distintos entre $\mathrm{si}^{43}$. Enquanto a relevância denota um aspecto qualitativo, referente à importância da questão debatida para o desenvolvimento do Direito; a transcendência possui um aspecto quantitativo, de modo que a questão debatida não fica circunscrita ao interesse subjetivo das partes, mas alcance também terceiros ${ }^{44}$.

Enquanto o instituto da relevância das questões federais infraconstitucionais mais se aproxima da repercussão geral das questões constitucionais, não há quase nenhuma semelhança com o instituto da arguição de relevância. Salvo a exigibilidade da relevância, característica que, inclusive, a diferencia da repercussão geral das questões constitucionais que, como já vimos, acrescenta a transcendência ${ }^{45}$.

O ideal seria harmonizar os requisitos de preenchimento dos filtros recursais para as questões constitucionais e infraconstitucionais, construindo um verdadeiro microssistema em que as regras sejam intercambiáveis entre si, prestigiando uma atuação uníssona do STF e STJ na análise desses requisitos. Em palavras diretas: é necessário acrescentar o requisito da transcendência junto ao da relevância ${ }^{46}$ e, além disso, seria mais adequado nominar o

\footnotetext{
${ }^{42}$ MARINONI, Luiz Guilherme; MITIDIERO, Daniel. Repercussão Geral no Recurso Extraordinário, p. 40. Contra, afirmando que "a relevância da questão debatida deve servir de parâmetro subsidiário", DANTAS, Bruno. Repercussão Geral, p. 249-250.

${ }^{43}$ Sobre relevância e transcendência como conceitos jurídicos indeterminados, $c f r$. MARINONI, Luiz Guilherme; MITIDIERO, Daniel. Repercussão Geral no Recurso Extraordinário, p. 40-47; TALAMINI, Eduardo. Repercussão geral em recurso extraordinário: nota sobre a sua regulamentação. Revista Dialética de Direito Processual, n. 54, p. 56-68, set. 2007, p. 57-58.

${ }^{44}$ Em sentido aproximado, Samuel Meira Brasil Jr. afirma que "os requisitos da repercussão geral são, portanto, dois: um de amplitude subjetiva (influência além dos interesses subjetivos das partes), outro de importância objetiva do tema (relevância social, política, econômica e jurídica)" (BRASIL JR., Samuel Meira. Precedentes Vinculantes e Jurisprudência Dominante na Solução de Controvérsias. Tese (Doutorado em Direito Processual) - Faculdade de Direito da Universidade de São Paulo, São Paulo, 2010, p. 255). Igualmente, TALAMINI, Eduardo. Repercussão geral em recurso extraordinário, p. 58.

${ }^{45}$ Há quem diga, porém, que "embora as palavras sejam distintas, o propósito da relevância da questão federal é, substancialmente, o mesmo da repercussão geral da questão constitucional” (MEDINA, José Miguel Garcia. Prequestionamento, Repercussão Geral da Questão Constitucional, Relevância da Questão Federal. $7^{\mathrm{a}}$ ed. São Paulo: RT, 2017, p. 128).

${ }^{46}$ Em sentido contrário, AURELLI, Arlete Inês Aurelli. A repercussão geral como requisito de admissibilidade
} 
Revista Eletrônica de Direito Processual - REDP.

Rio de Janeiro. Ano 13. Volume 20. Número 2. Maio a Agosto de 2019

Periódico Quadrimestral da Pós-Graduação Stricto Sensu em Direito Processual da UERJ

Patrono: José Carlos Barbosa Moreira (in mem.). ISSN 1982-7636. pp. 20-46

www.redp.uerj.br

instituto de repercussão geral das questões federais infraconstitucionais.

Isso porque é absolutamente possível que uma questão federal infraconstitucional seja relevante do ponto de vista econômico, político, social ou jurídico ${ }^{47}$, mas não transcender os interesses subjetivos do processo. Imagine-se, por exemplo, uma causa de grande proveito econômico envolvendo duas empresas, situação de inegável relevância econômica, mas que fica circunscrita ao interesse das partes. Nestas ocasiões, o STJ se pronunciar sobre o caso seria admiti-lo como uma instância recursal, modelo contrário ao proposto até então, pois apenas julgaria eventual injustiça do caso concreto, sem repercussão para além do processo individualmente considerado.

Ainda que o propósito dos institutos seja similar, são perceptíveis as diferenças entre a arguição de relevância, a repercussão geral das questões constitucionais e a relevância da questão federal, devendo, quanto a essas duas últimas, haver uma necessária harmonia.

\section{Questões PROCEDIMENTAIS: APRENDENDO COM A REPERCUSSÃO GERAL DAS QUESTÕES CONSTITUCIONAIS}

Para que o filtro recursal nos recursos especiais não cometa os mesmos erros da repercussão geral nos recursos extraordinários, algumas questões deverão observadas. Isso porque alguns problemas da repercussão geral já foram devidamente diagnosticados e, por conta disso, devem ser objeto de reflexão para que os equívocos não se repitam ${ }^{48}$.

do recurso especial - medida adequada?. In: NERY JR., Nelson; WAMBIER, Teresa Arruda Alvim; ALVIM, Angélica Arruda (coords.). Aspectos Polêmicos e Atuais dos Recursos Cíveis e Assuntos Afins. São Paulo: RT, 2017, vol. 13, p. 45-75, esp. 68.

${ }^{47}$ Para uma análise de critérios identificadores da repercussão geral das questões constitucionais, inclusive com individualização da relevância econômica, jurídica, política, social, cfr. FREITAS JR., Horival Marques de. Repercussão Geral das Questões Constitucionais: sua Aplicação pelo Supremo Tribunal Federal. São Paulo: Malheiros, 2015, p. 133-154.

48 Por todos, $c f r$. as propostas de Luís Roberto Barroso e Frederico Montedonio Rego: "1. A existência ou não de repercussão geral deve ser o primeiro exame a ser feito na apreciação de admissibilidade de um recurso extraordinário, o que assegurará transparência e celeridade na verificação do seu cabimento. Com isso será possível superar a prática até aqui prevalecente de fazer um 'juízo oculto' de relevância, pelo qual, sob a roupagem de um juízo técnico, o Tribunal recorre a fórmula defensivas de inadmissão, em que afirma que a matéria controvertida é infraconstitucional, fática ou não foi pré-questionada. 2. É possível a negativa de repercussão geral com efeitos limitados ao caso concreto e motivação sumária. O juízo de repercussão geral tem uma dimensão comparativa e inelutavelmente discricionária. A fundamentação objetiva é expressamente admitida pelo Código de Processo Civil para esse caso e o risco de arbitrariedade é minimizado pela exigência do quorum de 2/3 (dois terços). 3. A omissão de algum ministro em se manifestar deverá importar em adesão à posição do relator, o que impedirá, como já aconteceu muitas vezes, o reconhecimento de repercussão geral 
Revista Eletrônica de Direito Processual - REDP.

Rio de Janeiro. Ano 13. Volume 20. Número 2. Maio a Agosto de 2019

Periódico Quadrimestral da Pós-Graduação Stricto Sensu em Direito Processual da UERJ

Patrono: José Carlos Barbosa Moreira (in mem.). ISSN 1982-7636. pp. 20-46

www.redp.uerj.br

São três as mudanças necessárias: (i) em primeiro lugar, o exame da repercussão geral das questões federais infraconstitucionais deve anteceder o juízo de admissibilidade do recurso especial; (ii) em segundo lugar, as decisões denegatórias da repercussão geral das questões federais infraconstitucionais não precisam ser fundamentadas; (iii) em terceiro lugar, o filtro recursal deve ser exigido para a inclusão de matérias no âmbito de conhecimento do STJ, de modo que o ônus argumentativo deve ser pelo preenchimento dos requisitos da relevância e transcendência da questão federal infraconstitucional.

Em relação à primeira proposta, quando introduzida no sistema a repercussão geral das questões constitucionais, uma das maiores discussões doutrinárias sobre o tema recaía na natureza jurídica do instituto à luz da teoria geral dos recursos para definir o momento e plano de sua análise.

Sabidamente, a cognição recursal é marcada pela dicotomia entre o juízo de admissibilidade e o juízo de mérito: enquanto na primeira fase procede-se à "verificação da existência ou inexistência dos requisitos necessários para que o órgão competente possa legitimamente exercer sua atividade cognitiva no tocante ao mérito do recurso"; na segunda examina-se efetivamente a "matéria devolvida ao órgão competente com a interposição do recurso e que pode levar à anulação ou reforma da decisão impugnada"49.

Nos recursos excepcionais, esse processo é ainda mais complexo. Isso porque a cognição é tripartida em três operações sucessivas: (i) em primeiro lugar, há a verificação da admissibilidade do recurso; (ii) em segundo lugar, o exame concreto da existência da violação a dispositivo constitucional ou infraconstitucional (iudicium rescidens); (iii) por fim, em terceiro lugar, ocorre o rejulgamento da causa (iudicium rescissorium) ${ }^{50}$.

pela ausência de manifestação dos Ministros. 4. As ideias aqui veiculadas são plenamente compatíveis com a Constituição e a legislação aplicável, podendo ser instituídas, quando muito, por mera alteração regimental" (BARROSO, Luís Roberto; REGO, Frederico Montedonio. Como salvar o sistema de repercussão geral: transparência, eficiência e realismo na escolha do que o Supremo Tribunal Federal vai julgar. Revista Brasileira de Políticas Públicas, v. 7, n. 3, p. 695-713, 2017, p. 711).

49 JORGE, Flávio Cheim Teoria Geral dos Recursos Cíveis, p. 76 e 87.

${ }^{50}$ Nesse sentido, à luz do CPC/1973, BARBOSA MOREIRA, José Carlos. Comentários ao Código de Processo Civil, p. 402-403. Corroborando essa ideia, já na vigência do CPC/2015, cfr. FONSECA, João Francisco Naves da. A profundidade do efeito devolutivo nos recursos extraordinário e especial: o que significa a expressão ‘julgará o processo, aplicando o direito' (CPC/2015, art. 1.034)? Revista do Advogado, v. 126, p. 124-129, 2015; JORGE, Flávio Cheim. O julgamento dos recursos extraordinário e especial e os fundamentos (causa de pedir) da demanda. In: BEDAQUE, José Roberto dos Santos; YARSHELL, Flávio Luiz; SICA, Heitor Vitor Mendonça (orgs.). Estudos de Direito Processual Civil em homenagem ao Professor José Rogério Cruz e Tucci. Salvador: JusPodivm, 2018, p. 257-286. 
Revista Eletrônica de Direito Processual - REDP.

Rio de Janeiro. Ano 13. Volume 20. Número 2. Maio a Agosto de 2019

Periódico Quadrimestral da Pós-Graduação Stricto Sensu em Direito Processual da UERJ

Patrono: José Carlos Barbosa Moreira (in mem.). ISSN 1982-7636. pp. 20-46

www.redp.uerj.br

Parte da doutrina vem inserindo o instituto da repercussão geral dentro da primeira fase, relativa ao juízo de admissibilidade dos recursos, mas estabelecendo uma ordem preferencial de análise ${ }^{51}$. Primeiro seriam analisados os pressupostos intrínsecos e extrínsecos do recurso; depois, examinar-se-ia se a matéria debatida contém ou não repercussão geral. Essa ideia foi corroborada pelo Regimento Interno do STF, pois o art. 323, com a redação dada pela Emenda Regimental n. 42, de 2 de dezembro de 2010, afirma que "quando não for caso de inadmissibilidade do recurso por outra razão, o(a) Relator(a) ou o Presidente submeterá, por meio eletrônico, aos demais ministros, cópia de sua manifestação sobre a existência, ou não, de repercussão geral". A interpretação da expressão "por outra razão" justificaria a análise de outros requisitos de admissibilidade antes da repercussão geral.

Sendo assim, no caso do filtro recursal relativo às questões federais infraconstitucionais, o exame da relevância e transcendência deve ser anterior ao juízo de admissibilidade do recurso especial. Isso porque óbices formais podem ser superados em prol da unidade e desenvolvimento do Direito, ressalvadas as hipóteses de vícios graves, tal qual a intempestividade.

Em relação à segunda e à terceira proposta, sabe-se que o ônus argumentativo para decisões judicias que concretizam conceitos jurídicos indeterminados é deveras mais rigoroso, tanto que o art. 489, $\S 1^{\circ}$, II do CPC/2015 não considera fundamentada a decisão que emprega conceitos jurídicos indeterminados e não explica a razão concreta de sua incidência no caso.

Também se sabe que a fundamentação para aplicar um conceito jurídico indeterminado no caso concreto requer um labor argumentativo equivalente à fundamentação que justifica a não aplicação do conceito jurídico indeterminado. Assim, a decisão que entende preenchida a relevância e transcendência no recurso especial, em termos de fundamentação, é tão ou mais trabalhosa que a decisão que entende não estarem preenchidos os requisitos.

Ocorre, no entanto, que o caput do art. 1.035 do CPC/2015 afirma ser irrecorrível a

\footnotetext{
${ }^{51}$ Nesse sentido, ao que parece, TALAMINI, Eduardo. Repercussão geral em recurso extraordinário, p. 57; TUCCI, José Rogério Cruz e. Anotações sobre a Repercussão Geral como pressuposto de admissibilidade do Recurso Extraordinário (Lei 11.418/2006). Revista de Processo. Contra: NETTO, José Manoel de Arruda Alvim. A EC n. 45 e o instituto da repercussão geral, p. 76-78.
} 
Revista Eletrônica de Direito Processual - REDP.

Rio de Janeiro. Ano 13. Volume 20. Número 2. Maio a Agosto de 2019

Periódico Quadrimestral da Pós-Graduação Stricto Sensu em Direito Processual da UERJ

Patrono: José Carlos Barbosa Moreira (in mem.). ISSN 1982-7636. pp. 20-46

www.redp.uerj.br

decisão do STF que não reconhece a existência de repercussão geral da questão constitucional. A fundamentação, nesse caso, perde a razão de ser quanto à necessidade de controle endoprocessual, pois não tem aptidão de propiciar às partes e aos tribunais superiores (que nem existem, no caso específico) o conhecimento das razões de decidir para eventual reforma ${ }^{52}$.

É absolutamente contraproducente exigir que a Corte dispenda seu tempo de trabalho fundamentando decisões denegatórias da repercussão geral, aumentando a carga de trabalho do STJ para produzir fundamentações desnecessárias pela inexistência de relevância e transcendência, o que fere de morte o direito fundamental a uma tutela jurisdicional efetiva (art. 5 $5^{\circ}$ XXXV, CF/1988 e art. $4^{\circ}$ do CPC/2015).

Desse modo, é preciso que o sistema jurídico brasileiro parta da presunção de inexistência da relevância e transcendência da questão federal infraconstitucional, havendo um ônus argumentativo tanto da parte recorrente, quanto do relator no STJ, pelo preenchimento desses requisitos.

Assim, observadas essas três situações, haverá uma verdadeira otimização da atuação da Corte, colaborando para uma maior eficiência do instituto.

\section{ConClusões}

A excessiva carga de trabalho nos Tribunais Superiores não é um dado novo no sistema jurídico brasileiro. Mesmo assim, o problema não é enfrentado à luz de um quadro teórico adequado e tampouco leva em consideração a realidade pragmática.

A introdução de um filtro recursal de admissibilidade nos recursos especiais mostrase a saída para que o STJ se pronuncie apenas sobre questões federais infraconstitucionais dotadas de relevância e transcendência. Essa alteração poderá promover ganhos não só quantitativos, mas também qualitativos, na medida em que a Corte poderá dedicar seu tempo para julgamento de casos importantes ao desenvolvimento da ordem jurídica brasileira.

\footnotetext{
${ }^{52}$ Sobre a função endoprocessual e extraprocessual da fundamentação das decisões judiciais, $c f r$. TARUFFO, Michele. A Motivação da Sentença Civil. Trad. Daniel Mitidiero, Rafael Abreu e Vitor de Paula Ramos. São Paulo: Marcial Pons, 2015, p. 340; BARBOSA MOREIRA, José Carlos. A motivação das decisões judiciais como garantia inerente ao Estado de Direito. In: Temas de Direito Processual: Segunda Série. $2^{\text {a }}$ ed. São Paulo: Saraiva, p. 83-95, 1988.
} 
Revista Eletrônica de Direito Processual - REDP.

Rio de Janeiro. Ano 13. Volume 20. Número 2. Maio a Agosto de 2019

Periódico Quadrimestral da Pós-Graduação Stricto Sensu em Direito Processual da UERJ

Patrono: José Carlos Barbosa Moreira (in mem.). ISSN 1982-7636. pp. 20-46

www.redp.uerj.br

Especificamente, foi possível chegar às seguintes conclusões:

a) A história da gênese do recurso especial autoriza a introdução de um filtro recursal de seleção de caso para o STJ, dada a semelhança ontológica deste com o recurso extraordinário;

b) Uma análise do direito comparado revela constituir uma tendência mundial a inserção de filtros de admissibilidade lastreados em elementos qualitativos para seleção de casos;

c) É perfeitamente compatível com o STJ o modelo de uma Corte Suprema responsável por controlar a própria agenda, selecionando os casos que irá julgar com base na importância da matéria para o desenvolvimento da ordem jurídica infraconstitucional;

d) Os recursos especiais dirigidos ao STJ devem contar com um filtro recursal de admissibilidade baseado na relevância e transcendência da matéria federal infraconstitucional debatida;

e) O filtro recursal no recurso especial não restringe o acesso à justiça e nem tem o condão de perpetuar erros judiciais cometidos em instâncias ordinárias;

f) Sugere-se que o filtro recursal para os recursos especiais conjugue o binômio relevância-transcendência e seja denominado de repercussão geral das questões federais infraconstitucionais, a fim de harmonizá-lo com a repercussão geral das questões constitucionais;

g) Sugere-se a presunção de inexistência da repercussão geral das questões federais infraconstitucionais, cabendo à parte recorrente, no recurso especial, e ao relator, no STJ, demonstrar o preenchimentos dos requisitos de relevância e transcendência;

h) As decisões que reconhecem a inexistência da repercussão geral das questões federais infraconstitucionais não devem ser fundamentadas.

\section{REFERÊNCIAS}

AURELLI, Arlete Inês Aurelli. A repercussão geral como requisito de admissibilidade do recurso especial - medida adequada?. In: NERY JR., Nelson; WAMBIER, Teresa 
Revista Eletrônica de Direito Processual - REDP.

Rio de Janeiro. Ano 13. Volume 20. Número 2. Maio a Agosto de 2019

Periódico Quadrimestral da Pós-Graduação Stricto Sensu em Direito Processual da UERJ

Patrono: José Carlos Barbosa Moreira (in mem.). ISSN 1982-7636. pp. 20-46

www.redp.uerj.br

Arruda Alvim; ALVIM, Angélica Arruda (coords.). Aspectos Polêmicos e Atuais dos Recursos Cíveis e Assuntos Afins. São Paulo: RT, 2017, vol. 13, p. 45-75.

AZZONI, Clara Moreira. Recurso Especial e Extraordinário: Aspectos Gerais e Efeitos. São Paulo: Atlas, 2009.

BARBOSA MOREIRA, José Carlos. A motivação das decisões judiciais como garantia inerente ao Estado de Direito. In: Temas de Direito Processual: Segunda Série. $2^{\mathrm{a}}$ ed. São Paulo: Saraiva, p. 83-95, 1988.

A Suprema Corte Norte-Americana: um modelo para o mundo? In:

Temas de Direito Processual: Oitava Série. São Paulo: Saraiva, 2004, p. 239-251.

Comentários ao Código de Processo Civil. $15^{\mathrm{a}}$ ed. Rio de Janeiro: Forense, 2010, vol. V (arts. 476 a 565).

BARROSO, Luís Roberto; REGO, Frederico Montedonio. Como salvar o sistema de repercussão geral: transparência, eficiência e realismo na escolha do que o Supremo Tribunal Federal vai julgar. Revista Brasileira de Políticas Públicas, v. 7, n. 3, p. 695713, 2017.

BENEDUZI, Renato Resende. Repercussão geral no recurso especial por analogia. Disponível em <https://puc-rio.academia.edu/RenatoBeneduzi>. Acesso em 19.06.2018.

BONATO, Giovanni. O filtro ao recurso de cassação no sistema jurídico italiano. Revista de Processo, v. 40, n. 249, p. 249-274, nov. 2015.

BRASIL JR., Samuel Meira. Precedentes Vinculantes e Jurisprudência Dominante na Solução de Controvérsias. Tese (Doutorado em Direito Processual) - Faculdade de Direito da Universidade de São Paulo, São Paulo, 2010.

BUZAID, Alfredo. A crise do Supremo Tribunal Federal. Revista da Faculdade de Direito da Universidade de São Paulo, v. 55, p. 327-372, 1960

CABRAL, Antonio do Passo. Requisitos de relevância no sistema recursal alemão. In: FUX, Luiz; DANTAS, Bruno; FREIRE, Alexandre (orgs.). Repercussão Geral da Questão Constitucional. Rio de Janeiro: Forense, 2014, p. 71-85.

CALMON DE PASSOS, José Joaquim. Da arguição de relevância no recurso extraordinário. Revista Forense: Comemorativa - 100 anos, 2007, v. 1, p. 581-607.

CAPONI, Remo. La decisione della causa nel merito da parte della Corte di cassazione italiana e del Bundesgerichtshof tedesco. Diritto e Giurisprudenza, 1996, p. 236 e ss.

DANTAS, Bruno. Repercussão Geral: Perspectivas Histórica, Dogmática e de Direito Comparado - Questões Processuais. $2^{\mathrm{a}}$ ed. São Paulo: RT, 2009.

DANTAS, Bruno; GALLOTTI, Isabel. Relevância da questão federal e a função constitucional do recurso especial. In: FUX, Luiz; DANTAS, Bruno; FREIRE, Alexandre (orgs.). Repercussão Geral da Questão Constitucional. Rio de Janeiro: Forense, 2014, p. 129-160.

FONSECA, João Francisco Naves da. A profundidade do efeito devolutivo nos recursos 
Revista Eletrônica de Direito Processual - REDP.

Rio de Janeiro. Ano 13. Volume 20. Número 2. Maio a Agosto de 2019

Periódico Quadrimestral da Pós-Graduação Stricto Sensu em Direito Processual da UERJ Patrono: José Carlos Barbosa Moreira (in mem.). ISSN 1982-7636. pp. 20-46

www.redp.uerj.br

extraordinário e especial: o que significa a expressão "julgará o processo, aplicando o direito" (CPC/2015, art. 1.034)? Revista do Advogado, v. 126, p. 124-129, 2015

FREITAS JR., Horival Marques de. Repercussão Geral das Questões Constitucionais: sua Aplicação pelo Supremo Tribunal Federal. São Paulo: Malheiros, 2015.

GIANINNI, Leandro J. El certiorari en Argentina: la trascendencia como filtro de selección ante la Corte Suprema. Revista de Processo, v. 41, n. 251, p. 229-273, jan. 2016.

GRINOVER, Ada Pellegrini. Ensaio Sobre a Processualidade: Fundamentos para uma Nova Teoria Geral do Processo. Brasília: Gazeta Jurídica, 2017.

JORGE, Flávio Cheim. O julgamento dos recursos extraordinário e especial e os fundamentos (causa de pedir) da demanda. In: BEDAQUE, José Roberto dos Santos; YARSHELL, Flávio Luiz; SICA, Heitor Vitor Mendonça (orgs.). Estudos de Direito Processual Civil em homenagem ao Professor José Rogério Cruz e Tucci. Salvador: JusPodivm, 2018, p. 257-286.

Teoria Geral dos Recursos Cíveis. 7ª ed. São Paulo: RT, 2015.

LAMY, Eduardo de Avelar. Repercussão geral no recurso extraordinário: a volta da arguição de relevância?. In: WAMBIER, Teresa Arruda Alvim et al (orgs.). Reforma do Judiciário. São Paulo: RT, 2005, p. 167-180.

LASPRO, Orestes Nestor de Souza. O Duplo Grau de Jurisdição no Processo Civil. São Paulo: RT, 1995.

LEAL, Victor Nunes. Aspectos da reforma judiciária. Revista de Informação Legislativa, v. 2, n. 7, p. 15-46, set. 1965.

LIMA, Alcides de Mendonça. Arguição de relevância da questão federal. Revista de Processo, v. 15, n. 58, p. 118-119, abr./jun. 1990.

MACIEL, Adhemar Ferreira. Restrição à admissibilidade de recursos na Suprema Corte dos Estados Unidos e no Supremo Tribunal Federal do Brasil. Revista de Informação Legislativa, a. 43, n. 170, p. 7-15, abr./jun. 2006.

MANCUSO, Rodolfo de Camargo. Recurso Extraordinário e Recurso Especial. 13ª ed. São Paulo: RT, 2015.

MARINONI, Luiz Guilherme. O STJ enquanto Corte de Precedentes: Recompreensão do Sistema Processual da Corte Suprema. $2^{\mathrm{a}}$ ed. São Paulo: RT, 2014.

MARINONI, Luiz Guilherme; MITIDIERO, Daniel. Repercussão Geral no Recurso Extraordinário. $3^{\mathrm{a}}$ ed. São Paulo: RT, 2012.

MEDINA, José Miguel Garcia. Prequestionamento, Repercussão Geral da Questão Constitucional, Relevância da Questão Federal. $7^{\text {a }}$ ed. São Paulo: RT, 2017.

MEDINA, Paulo Roberto de Gôuvea. Arguição de relevância no STJ. Revista Brasileira de Direito Processual, v. 25, n. 98, p. 357-363, abr./jun. 2017

MITIDIERO, Daniel. Cortes Superiores e Cortes Supremas: do controle à interpretação, da jurisprudência ao precedente. $3^{\text {a }}$ ed. São Paulo: RT, 2017.

NETTO, José Manoel de Arruda Alvim. A alta função jurisdicional do Superior Tribunal de 
Revista Eletrônica de Direito Processual - REDP.

Rio de Janeiro. Ano 13. Volume 20. Número 2. Maio a Agosto de 2019

Periódico Quadrimestral da Pós-Graduação Stricto Sensu em Direito Processual da UERJ

Patrono: José Carlos Barbosa Moreira (in mem.). ISSN 1982-7636. pp. 20-46

www.redp.uerj.br

Justiça no âmbito do recurso especial e a relevância das questões. Revista de Processo, v. 24, n. 96, p. 37-44, out./dez. 1999.

A EC n. 45 e o instituto da repercussão geral. In: WAMBIER, Teresa Arruda Alvim; et al (coords.). A Reforma do Judiciário: Primeiras Reflexões sobre a Emenda Constitucional n. ${ }^{\circ}$ 45/2004. São Paulo: RT, 2005, p. 63-99.

Argüição de Relevância no Recurso Extraordinário. São Paulo: RT, 1988.

OTEIZA, Eduardo. El certiorari o el uso de la discrecionalidad por la Corte Suprema de Justicia de la Nación sin rumbo preciso. Revista Jurídica de la Universidad de Palermo, año 3, n. 1, p. 71-85, 1998.

PEREIRA, Paula Pessoa. Legitimidade dos Precedentes: Universabilidade das Decisões do STJ. São Paulo: RT, 2014.

PÉREZ RAGONE, Alvaro J. El nuevo proceso civil alemán: principios y modificaciones al sistema recursivo. Genesis - Revista de Direito Processual Civil, v. 9, n. 32, p. 357384, abr./jun. 2004.

RODOVALHO, Thiago. O STJ e a arguição de relevância. In: GALOTTI, Isabel et al (coords.). O Papel da Jurisprudência no STJ. São Paulo: RT, p. 835-854, 2014.

SARLET, Ingo Wolfgang; MARINONI, Luiz Guilherme; MITIDIERO, Daniel. Curso de Direito Constitucional. 6 ${ }^{\mathrm{a}}$ ed. São Paulo: RT, 2017.

SERAU JR., Marco Aurélio; DONOSO, Denis. Relevância da questão federal como filtro de admissibilidade do recurso especial: análise das propostas de emenda constitucional. Revista de Processo, v. 38, n. 224, p. 241-251, out. 2013.

SILVA, José Afonso da. Do Recurso Extraordinário no Direito Processual Civil Brasileiro. São Paulo: RT, 1963.

SILVA, Ovídio Araújo Baptista da. A Função dos Tribunais Superiores. In: Sentença e Coisa Julgada: Ensaios e Pareceres. $4^{\text {a }}$ ed. Rio de Janeiro: Forense, 2006, p. 285-305.

TALAMINI, Eduardo. Repercussão geral em recurso extraordinário: nota sobre a sua regulamentação. Revista Dialética de Direito Processual, n. 54, p. 56-68, set. 2007.

TARUFFO, Michele. A Motivação da Sentença Civil. Trad. Daniel Mitidiero, Rafael Abreu e Vitor de Paula Ramos. São Paulo: Marcial Pons, 2015.

TUCCI, José Rogério Cruz e. Anotações sobre a Repercussão Geral como pressuposto de admissibilidade do Recurso Extraordinário (Lei 11.418/2006). Revista de Processo, v. 32, n. 145, p. 151-162, mar. 2007.

ZANETI JR., Hermes. A Constitucionalização do Processo: o Modelo Constitucional da Justiça Brasileira e as Relações entre Processo e Constituição. $2^{\mathrm{a}}$ ed. São Paulo: Atlas, 2014.

O Valor Vinculante dos Precedentes: Teoria dos Precedentes Normativos Formalmente Vinculantes. $3^{\text {a }}$ ed. Salvador: JusPodivm, 2017. 